\title{
Osmnáctá konference Evropské asociace pro studium náboženství (EASR)
}

\section{MiCHAL PUCHOVSKÝ - JANA NENADALOVÁ}

Väčšina z religionistov si v priebehu rokov 2020 a 2021 užila svoj podiel virtuálnych "gaučových" konferencií. Aj ked" má svoje čaro chrúmat obed a popíjat čaj v pyžame popri počúvaní zaujímavých prednášok, mágii konferenčných stretnutí sa to nevyrovná. Vytúžené uvolnenie epidemiologických podmienok na cestovanie a organizáciu hromadných akcií umožnilo opätovné uskutočnenie medzinárodných konferencií. Tradičná medzinárodná konferencia Európskej asociácie pre štúdium náboženstiev (EASR) sa v roku 2021, po ročnej vynútenej pauze a v hybridnej podobe, odohrala od 30. augusta do 3. septembra v talianskej Pise. Podobne ako po minulé roky, aj osemnásteho ročníka sa zúčastnilo množstvo zástupcov z českých univerzít. Dvaja účastníci z radov nastupujúcej generácie bádatelov Michal Puchovský a Jana Nenadalová - si rozdelili prácu a v nasledujúcej spoločnej reportáži ponúkajú svoje pohlady na konferenčné dianie.

\section{Prvýkrát na vel'kej konferencii}

EASR konferencie patria $\mathrm{k}$ mamutím akciám, ktorých sa zúčastňujú stovky bádatelov, primárne z Európy. Pre mňa ako začínajúceho bádatela bola účasṫ na konferencii po mnohých stránkach výzvou. Ako zapadnem do kolektívu skúsených bádatelov? Obstojí môj konferenčný príspevok v konkurencii špičiek odboru?

Po prílete do Pise v pondelok 30. augusta poobede som sa stihol akurát tak ubytovat a následne sa zúčastnit úvodnej recepcie na počest̉ zahájenia konferencie. V utorok sa rozbehla konferencia naplno a ubiehala vo vysokom tempe, od 9:00 ráno až do 18:00. Paralelne išlo v priemere jedenást’ panelov v hybridnej forme. To prinášalo nielen klasickú dilemu: „Kam íst?", ale aj nekonečné množstvo komplikácií, či už s vypadávajúcim internetom alebo nedostatkom technickej podpory. V priebehu týždňa sa naštastie situácia zlepšovala a problémy sa priebežne odstraňovali.

Samotné priestory, v ktorých sa odohrávala konferencia, boli viac než dôstojné. Budova Pensionato Universitario Toniolo poskytla dostatok 
miestností na prednášky, aj ked’ sa v nej človek sem-tam strácal. Pocity religionistickej relevancie dodali miestu rôzne fotky a mal'by svätých či pápeža, ktoré sa stali častým terčom bodrých komentárov prednášajúcich. Parčík vo vnútri budovy zase poskytol priestor na obedy a rozhovory počas páuz medzi prednáškovými blokmi. Kohokolvek ste mohli oslovit a začat s ním rozhovor o religionistike, prípadne s ním prediskutovat jeho prednášku. Z ludí bolo cítit hlad po ludskom kontakte, čo len umocňovalo velmi dobrú konferenčnú atmosféru. Vrcholom komunitnej stránky konferencie bol nepochybne štvrtkový večierok spojený s trojchodovou večerou, dobrým pitím a vzdaním holdu organizátorke konferencie - Chiare O. Tommasi.

Na margo kvality konferenčných príspevkov môžem dodat asi tol'ko, že drvivá príspevkov mala velmi vysokú úroveň. Akceptovaní prednášajúci ovládali umenie prednesu a ich výskumy boli prepracované po teoretickej, analytickej aj výskumnej rovine. Osobne som vyhladával prednášky súvisiace s mojou špecializáciou na nové náboženské hnutia (konkrétne novopohanstvo) a náboženstvo v strednej a východnej Európe. Preto asi neprekvapí, že za vrchol konferencie považujem štvrtkový celodenný panel venovaný novopohanstvu a spiritualitám New Age, v rámci ktorého som vystúpil s príspevkom na tému: „Českí novopohania, COVID a rituálny život počas pandémie“. Vyvážený podiel výskumníkov z rôznych kútov Európy a Spojených štátov s pestrou škálou príspevkov poukázal na špecifiká a podobnosti prístupu novopohanstiev ku komplikáciám spôsobeným COVID-19. Za vel'ké pozitívum konferencie môžem taktiež považovat nielen vysoký podiel bádatelov zo strednej a východnej Európy, ale aj počet príspevkov venujúcich sa špecificky jej náboženskej situácii či dejinám. V nadväznosti na túto stránku môžem spomenút série piatkových prednášok organizovaných mad’arskými religionistami na čele s Andrásom MatéTóthom, neúnavným propagátorom alternatívnej stredno-východoeurópskej sekularizačnej teórie „wounded identities”. Podobné snahy si aj napriek ich problematickým miestam zaslúžia pozornost', pretože pomáhajú dekolonizovat bádanie o náboženstve v post-sovietskom priestore.

\section{Italská konferenční pohoda}

Do Pisy jsme já a moje kolegyně z LEVYNA Kateřina Koppová přiletěly s dvoudenním předstihem, protože př́imý letecký spoj z Prahy sem létá jen jednou týdně. Př́ijemně nás překvapila pohodová maloměstská atmosféra jinak turistické Pisy i návrat z českého babího léta k letnímu počasí, a proto jsme hned vyrazily obhlédnout místní památky, abychom se pak zbytek týdne mohly v klidu věnovat konferenčnímu dění. 
Neděle a také následující dny se nesly hlavně ve znamení bujarého společenského družení. Většina religionistů a spřízněných badatelů se přijela do Pisy kromě odborného zájmu také socializovat. Přednáškové panely, obědové pauzy i večerní program proto provázelo čilé navazování kontaktů a vyměňování informací ohledně dění na nejrůznějších evropských univerzitách, o našich vlastních výzkumech a často i o plánech do budoucna. Vzhledem k evropskému formátu akce bylo možná až trochu úsměvné, že vedle logicky vysokého počtu Italů se v Pise setkalo tolik doktorandů a mladých badatelů z České i Slovenské republiky. Protože moje přednáška byla $\mathrm{v}$ programu zařazena až na úplný závěr (byla jsem posledním řečníkem v posledním panelu posledního dne), měla jsem alespoň dostatek času lákat na svou přednášku ostatní účastníky konference, což se mi nakonec vyplatilo.

Přednášky, kterých jsem se účastnila, měly poměrně kolísavou úroveň - od opravdu zajímavých a kvalitně odprezentovaných až po teatrální projev $\mathrm{v}$ italštině, $\mathrm{z}$ něhož jsem sice rozuměla jen pár slov, samotný vizuální vjem ale $\mathrm{k}$ zábavě bohatě dostačoval. Vzhledem $\mathrm{k}$ hybridnímu formátu konference se ale bohužel často stávalo, že online řečníci nebyli př́liš slyšet.

Italský přístup “montáží na koleni” a nespěchání nikam mi byl vlastně nakonec př́ijemný. Očekávala jsem masovou a hektickou akci a dostala klidnou, rodinnou, vínem a italským jídlem provoněnou letní pohodu. Atmosféru celé akce ještě umocnil koncert v kostele a všudypř́itomné kapary, vyrůstající ze starých antických zdí. Poslední den jsem nakonec přišla s přednáškou na řadu i já a díky Káti, která si všimla volného přednáškového sálu - většího než malá místnůstka, kde měl původně probíhat můj panel - se mi nakonec v publiku sešel i celkem slušný počet posluchačù, a dokonce mi v rámci rozlučky před přednáškou bouchli láhev šumivého vína. Itálie, jak má být.

\section{Závěrem}

I přes různé technické patálie se konference EASR 2021 rozhodně povedla. Občasné nedostatky $\mathrm{v}$ profesionalitě provedení bohatě vyvážila celková atmosféra místa a př́ijemní lidé. Jedna kolegyně z Norska, která na EASR jezdí už mnoho let, nás dokonce ubezpečila, že „takto rodinnou atmosféru mívaly EASRy ve svých začátcích“. Př́iští rok sice možná EASR něco z této své rodinné tváře ztratí, pokud se nám opravdu podaří porazit pandemii COVIDu-19 a navrátí se původní rozměry konference, určitě ale neztratí nic ze svého otevřeného a přátelského ducha. Takže ciao zase za rok, tentokrát v zeleném Irsku! 